\title{
Uno de tantos crímenes literarios
}

\author{
One of so many literary crimes
}

\author{
Oscar Eliezer Mendoza de los Santos \\ Universidad Autónoma de Tamaulipas \\ México
}

E lla toma el cuchillo y lo dirige al pecho de aquel hombre incauto. Un aluvión de preguntas comienza a inundar su mente que, hasta hacía un instante, estaba en blanco. ¿Por qué carajos estoy haciendo esto? ¿Cómo llegué aquí?". El arma se clava de lleno, ante el horror e impotencia de la mujer, cuyas manos titubeantes se tiñen de sangre. Consternada, intenta caer de rodillas, pero le es imposible aun; sus piernas son como dos postes clavados al concreto. En vez de eso, empieza a mirar con ojos exorbitados a la muchedumbre que, con morbosidad, graba el evento. "i¿Por qué mierda graban, malnacidos?!", espeta con furia. Pero, en breve, un miedo aun más grande se apodera de ella. “QQué... pasa con ustedes?”. Un hombre sin ojos ni nariz le dice algo a otro que ni si quiera tiene orejas. Ambos sonríen efusivamente. Alguien, al parecer más sensato, marca al número de emergencias, haciendo uso de un teléfono que no está en ninguna parte.

Para la mujer, nada tiene sentido. Unos instantes atrás ni siquiera existía y ahora está aquí, como perpetuadora de un terrible crimen, intentando respirar con una calma que nunca ha conocido, mientras alrededor suyo una humanidad de mutilados maniquíes y edificios a medio construir se despliegan en lo que parece ser una obra inconclusa. Pero, aquí, el tiempo distorsionado pasa muy rápido, y el temor, lo mismo que la vida, no dura demasiado. Los ojos se le están inundando en lágrimas de vergüenza. "¿Qué dirá su familia? ¿Sus amigos? ¿Qué dirá Dios? “¿Dónde están todos ellos?”, se cuestiona, mientras levanta la mirada y, con el alma en agonía, se percata que no hay un cielo acabado al cual mirar, solo un hueco enorme de infinita negrura.

Un desliz en mi escritura le revela algo. Con pulso febril, he tenido que borrar y reescribir, pero creo que es muy tarde. ¡Qué calamidad! Cual criatura salvaje, exaltada, ahora intuye mi presencia. Con los dientes apretándose unos contra otros, al borde del quiebre, se pone a lanzar cuchilladas al aire. Esta segunda parte del acto despierta aún mayor desprecio en los observadores. 
Una botella, proveniente de quién sabe dónde, le da directo en la cabeza. "AAsesina!", grita alguien. Un riachuelo carmesí le escurre por el rostro pálido y desencajado. “'Asesina!”, gritan ahora todos, al unísono, incluso aquellos que no tienen boca.

Me parece, hasta donde sé, que la sociología no lo explica de esta forma en ningún manual, pero muchedumbres solamente las hay de dos tipos: aquellas que son una mera pared impávida, cuya acción en la vida es menos que un simulacro. Y aquellas otras que, siendo también pared, se derrumban sobre unos cuantos para aplastarlos. Nuestra protagonista -porque, ciertamente, aún no he decidido como tendría que llamarle- está comenzando a sentir los ladrillos caer sobre ella.

Por fin de rodillas en el suelo, sangrando y cansada, solloza por esta suerte que no se explica cómo se ha forjado. El aturdimiento, la sangre y las lágrimas se sienten tan reales, tan externos a ella. "Real...", murmura para sí misma. El efecto del botellazo prontamente se disipa, y la lucidez vuelve a sus ojos, iluminados por un descomunal brillo. No se ha olvidado de mi presencia. Más aún, ha comprendido todo.

Hace unos instantes ni siquiera existía, cierto, pero ahora es muy consciente de que es parte de esta obra inconclusa. Por sus venas están corriendo letras y en sus genes han sido escritas escenas preconcebidas desde antes que ella misma existiera. Mira ahí, se está poniendo de pie. Ha vuelto a tomar el cuchillo y me amenaza con clavárselo en su propio corazón. Todos gritan consternados. ¡Quietos, ladrillos! Es mejor que guarden silencio.

Esos ojos negros, tan penetrantes como la noche más aciaga, me observan. De seguir yo escribiendo, esto terminará de un solo modo. Considero, pues, que debo tomarme un tiempo para sopesar este final. Tal vez sea prudente reescribir la historia completa. Ella se niega a esa idea y grita con rabia desgarradora. Supongo que una vida, aunque mala, es una vida, y es mejor que la nada.

No quiero ser autocompasivo, pero debo enfatizar que casi nadie concibe lo difícil que es escribir sin hacer daño. Casi nadie se percata de que todo personaje literario es nuestra víctima, una vez que ha llegado a nuestras páginas, secuestrado entre marañas de palabras.

Mi padre me decía que no intentara ser escritor, que no cometiera su error. Mi cordura no soportaría la responsabilidad de tener que decidir sobre tantas vidas. "Lo bueno, si breve, dos veces bueno", repetía hasta el hartazgo, para justificar sus cada vez más lacónicos cuentos y lo efímero de sus personajes. Me maravillaba, sin embargo, que fuera capaz de contar algo con tan pocas palabras. En algún momento, ya no le fue posible lidiar con la vida de ningún personaje, incluida la propia. Quizá pensó que lo malo, si poco, no tan malo. Tal vez, para él, la nada era mejor que una vida.

Pero heme aquí, espantando sus consejos que, como persistentes moscas, vuelan sobre mi cabeza. Necesito mucha cordura para sopesar detalladamente mi siguiente decisión, qué hilo he de cortar o mover, qué camino trazar. Deliberando con sumo cuidado en qué forma concluir una historia que ni siquiera tiene principio. ¡Qué pesado! ¡Maldición!

Ella sigue ahí, amenazando su vida y, por ende, mi obra. Pero ¿cómo podría culparla? En cambio, ¿alguien podría culparme a mí?

No seré yo quien responda, pues me estoy demorando demasiado y el cuchillo está por atravesar su pecho... Ya voy a cerrar mi libreta. 